reaching universal solutions more implicitly. On the other hand, her evident empathy for, and involvement with, her interviewees are exemplary, whether as a health care professional (she has a nursing background) or as a social scientist.

The book overall is a very interesting way of projecting some of the multitude of personal and social ethical issues arising out of the AIDS pandemic, from a North American standpoint; many of the issues travel well, however. The author's skilful eliciting and selection of these simple and direct expressions of the human conflicts arising from this epidemic will be thought-provoking for people who want to understand it better, whether they are familiar with the issues or not and whether they are health care workers, ethicists or lay people.

PROFESSOR ANTHONY J PINCHING

Professor of Immunology,

Medical College of St Bartholomew's

Hospital,

West Smithfield,

London EC1A 7BE, UK.

\section{Ethics in obstetrics and gynecology}

Edmund D Pellegrino and David C Thomasma, Oxford and New York, Oxford University Press, 1994, 278 pages, $£ 30.00$

\section{Human in vitro fertilisation: a case study in the regulation of medical innovation}

\author{
J Gunning and V English, Aldershot \\ and Vermont, Dartmouth Publishing \\ Co, 1993, 219 pages, $£ 35.00$
}

The area of reproductive medicine is one of particular importance for ethics, because the arrangements surrounding sex and reproduction have always been central to social order and convention, and are often surrounded with mystique, taboo and religious and social significance.

In most societies, family, household and kinship relations are all bound up with these basic biological functions, and these, of course, are the underpinning of economic and ultimately political order. So the serious treatment of these issues in relation to recent scientific innovation in reproductive technology is to be welcomed.

Ethics in Obstetrics and Gynecology is a helpful book for those working in these areas, addressing itself essentially to professionals, but also of interest to the concerned general reader. In addition, it will be a useful source of comment and argument for those whose main interest is in the legal aspects, and although written within the context of American law, the principles involved are of equal interest to European and British legal theorists, who are also under a pressing necessity to reach consensus on a number of contentious issues in the area of reproductive medicine.

The book covers a wide range of topics including contraception and abortion, embryo selection and destruction, IVF and surrogacy, prenatal diagnosis and its consequences, HIV infection, uterine cancer, the premature infant, and issues surrounding childbirth itself, including the controversial issue of court-ordered caesarean deliveries.

The conflict that some of these issues generate between the patient and the person responsible for his/her health-care is a central focus for the authors, who recommend as a solution prevention and, where this is impossible, techniques of crisis management based on a virtues approach. This is in contrast to the more familiar approach which has become current in medical ethics literature, where a utilitarian ethic is set against a morality of inflexible principles, and the student is left with the impression that there is no ethical certainty - that relativism rules. Pellegrino and Thomasma argue for rather more conviction than this, proposing and seeking to justify a framework for ethical medicine based on the virtues of self-effacement, self-sacrifice, compassion and integrity. Underlying these are the broader ethical principles of beneficence and respect for autonomy.

Where a number of philosophers writing on the subject, in particular, of abortion, have taken up a position with very serious practical implications on the basis of abstract discussion of the notion of personhood, these authors who, perhaps because they represent a fruitful collaboration between a medical ethicist and a practitioner who is in day-to-day contact with patients, take seriously the concept of the fetus as a patient - and thus an object of moral concern. The $\frac{\widehat{D}}{\mathbb{D}}$ interests and involvement of other 2 family members too, in particular $\underset{\sim}{\mathrm{m}}$ fathers, are also given a weight that they have conspicuously failed to be granted in the current literature.

Human in Vitro Fertilisation has more limited aims. Written primarily with UK interests in mind, but providing a $\frac{\bar{\sigma}}{\overline{0}}$ useful summary of the legal position in $\frac{\sigma}{\gamma}$ various other countries, it records the $\stackrel{\mathbb{Q}}{\varrho}$ ethical debate surrounding the devel- o opment of IVF technology from the $s$ earliest researches of Robert Edwards, $\vec{\circ}$ Patrick Steptoe and others, to the birth $\vec{\overrightarrow{ }}$ of Louise Brown in Oldham in 1978, $\omega$ and beyond this to controversies generated by the latest reproductive tech- $\mathbb{D}$ nologies. This throws an interesting iv light on the extent to which current $\vec{\omega}$ practices have gone far beyond what the original pioneers believed would be $\mathscr{\varrho}$ ethically permissible.

The authors document the setting 0 up of ethical bodies in both the USA and Britain, and interestingly record $\vec{C}$ one of the earliest submissions of $\frac{\nwarrow}{5}$ Edwards to the USA Ethics Advisory $\mathbb{D}$ Board in which he wrote: 'We feel $\overrightarrow{0}$ strongly that any ethical decisien of about such work should be the responsibility of the patient, th doctor and the funding organization (page 18).

This notion that these were private decisions has long been abandoned, as $\frac{\mathbb{D}}{2}$ the public implications of private deci- $\overrightarrow{\vec{O}}$ sions have become apparent. Gunning and English have supplied a text which documents this shift, in particular describing the creation of the Voluntary Licensing Authority in $\overline{3}$ Britain, the reasons for the commis- $\mathbb{D}$ sioning of the Warnock Report, and subsequent legislative concerns and developments.

Readers of both these volumes will gain a broader and more informed 0 view of many important issues which have yet to be resolved.

\section{BRENDA ALMOND N Department of Philosophy, $\mathrm{N}$ University of Hull $\mathrm{N}$}

\section{Xenotransplantation}

Edited by Dr C Cooper, E Kemp, K Reemtsma and D J G White, Berlin, Springer-Verlag, 1991, 555 pages, DM420 hb

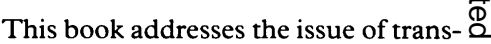
plantation of organs between species $\overline{-}$ with the purpose of saving human lives by sacrificing animals. 
It is predominantly a technicalscientific book with only one chapter out of 35 devoted to the ethical aspects of xenotransplantation. This chapter is written by $\operatorname{Dr} \mathrm{R} \mathrm{A}$ Wright, Director of the Biomedical and Health Care Ethics Program, at the University of Oklahoma Health Sciences Center. An overview of the arguments pro et contra is given in an ethical framework, referring to the moral worth of actions in terms of consequences, duties, and rights, the duties consisting of observing the principles of beneficence, non-maleficence, autonomy, and justice.

The overview is well written and is a good introduction to the ethical debate about xenotransplantation. It therefore seems to fit well with the rest of the book, which will most probably be read by those whose main interest is technical-scientific and who might have little knowledge of medical ethics.

For those familiar with the principles of ethical argument, however, the chapter is less interesting. The words deontology and utilitarianism are not even mentioned and it is not a deeply penetrating philosophical analysis. After some of the positions have been described, one is left with the feeling that important arguments are missing. For example, there is discussion about whether animals have rights at all or whether their possible rights are overridden by the rights of humans. A recursion to arguments for slavery would have been relevant, since they followed the same lines: slaves had no rights, or they were regarded as belonging to a lower degree of mankind, or the use of them was defended on utilitarian grounds. Similarly, the discussion on 'speciesism' and the literature showing that there is no metaphysical difference between humans and animals could have covered the obvious lack of logic in much current ethical debate to do with experimentation on fertilized human eggs whereby this is sometimes forbidden, the only reason being that the eggs are human; while at the same time, experiments on chimpanzees and their possible use in xenotransplantation are advocated, disregarding the fact that the intellectual capacity of a chimpanzee by far exceeds that of a small child.

\section{DR PETER C GØTZSCHE Epidemiafdeling $M$, Righospitalet, Tagensvej 20 \\ DK-2200 Kobenhavn N, Denmark}

\section{Family planning: practice and law}

Kenneth McK Norrie, Aldershot, Dartmouth Publishing, 1991, 203 pages, $£ 27.50 \mathrm{hb}$

The ethical and legal issues surrounding contraception have been so extensively discussed in recent years that any new work has something of a presumption to overcome as to its usefulness. Kenneth Norrie's book overcomes this effortlessly, providing a detailed and well-researched treatment of the many areas of this controversial area of law. For the reader interested in the ethical dimensions of the matter, there is a great deal of value in this work as well, in that it is impossible to separate the legal decisions on these issues from the general moral debate.

Some of the issues canvassed by Norrie are familiar features of the literature; others have attracted less attention. One of the latter is the question of the rights of sexual partners, a matter to which Norrie devotes an entire chapter. This chapter begins with the warning: 'It should never be forgotten that the process of human reproduction necessarily requires two individuals'. Forewarned, we then read that 'reproduction may take two, but birth control requires only one'. That, really, is the problem, and Norrie proceeds to give an exceptionally thought-provoking account of how this problem has been addressed in the law. Such cases as there are have been have tended to be concerned with abortion, and arguments as to any right of the father to prevent an abortion have been coldly received by the courts. Nor does the law give any right of consultation on the matter, taking the view that the matter is solely for the person whose body is affected by the procedure.

This emphasis on the rights of the individual is evident as well in other areas. In relation to the question of the sterilization of the mentally disabled, although this has been legally permitted, subject to various safeguards, Norrie points out that the grounds of permissibility have tended to be what is in the best interests of the individual rather than any social interest. Nor, it would seem, do the interests of carers weigh in the decision, except in so far as these affect the disabled individual.

This book is written with great clarity and makes easily intelligible reading for the non-lawyer. For those interested in how society has responded, through law, to this often touchy question, Norrie's work is a first-class contribution to the literature.

SANDY MCCALL SMITH Department of Private Law, University of Edinburgh, Old College, South Bridge, Edinburgh EH8 9YL

\section{Books: information and orders}

If you wish to order or require further information regarding the titles reviewed here, please write to or telephone the BMJ Bookshop, PO Box 295, London WC1H 9JR. Tel: 0171383 6244. Fax: 01713836662. Books are supplied post free in the UK and for BFPO addresses. Overseas customers should add 15 per cent for postage and packing. Payment can be made by cheque in sterling drawn on a UK bank or by credit card (Mastercard, Visa, or American Express, stating card number, expiry date, and full name (The price and availability are occasionally subject to revision by the publishers). 